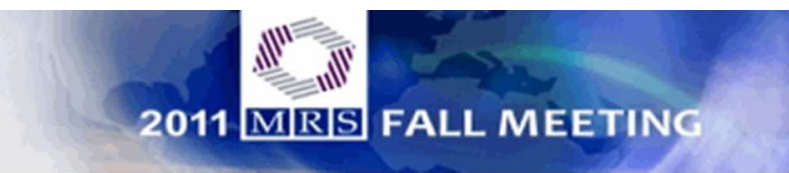

\title{
Multi-Electron-Transfer Catalysts Needed for Artificial Photosynthesis.
}

\begin{tabular}{|r|l|}
\hline Journal: & 2011 MRS Fall Meeting \\
\hline Manuscript ID: & Draft \\
\hline Manuscript Type: & Symposium E \\
\hline Complete List of Authors: & $\begin{array}{l}\text { Vickers, James; Emory University, Chemistry } \\
\text { Lv, Hongjin; Emory University, Chemistry } \\
\text { Zhuk, Petro; National Aviation University, } \\
\text { Geletii, Yurii; Emory University, Chemistry } \\
\text { Hill, Craig; Emory University, Chemistry }\end{array}$ \\
\hline Keywords: & catalytic, kinetics, oxidation \\
\hline & \multicolumn{2}{|l}{} \\
\hline
\end{tabular}

SCHOLARONE ${ }^{\text {"x }}$

Manuscripts 


\title{
Multi-Electron-Transfer Catalysts Needed for Artificial Photosynthesis
}

\author{
James Vickers ${ }^{1}$, Hongjin Lv ${ }^{1}$, Petro F. Zhuk ${ }^{2}$, Yurii V. Geletii ${ }^{1}$, and Craig L. Hill ${ }^{1}$ \\ ${ }^{1}$ Department of Chemistry, Emory University, Atlanta, Georgia 30322, U.S.A. \\ ${ }^{2}$ National Aviation University, Kiev, Ukraine
}

\begin{abstract}
We report a study on catalytic water oxidation by cobalt in oxygen ligand environments because such systems are as promising as any in the water oxidation component of solar fuel production. We have re-examined the catalytic activity of $\mathrm{Co}$ (II) in aqueous solution using either $\left[\mathrm{Ru}(\mathrm{bpy})_{3}\right]^{3+}$ as a stoichiometric oxidant or in visible-light-driven reactions with persulfate as a sacrificial electron acceptor. In both systems a distinctive induction period is observed. A simple kinetic model is proposed that describes the experimental data well. The presence of an induction period is explained by relatively slow formation of the true catalyst from aquacobalt(II).
\end{abstract}

\section{INTRODUCTION}

Modern, urban life on this planet is based on energy obtained primarily ( $\sim 80 \%$ in several developed countries) from fossil fuel. At the same time less than $0.02 \%$ of available solar energy is sufficient to entirely replace fossil fuels and nuclear power as an energy source.

Photosynthetic organisms produce more than 100 billion tons of dry biomass annually with a low energy efficiency $(<1 \%)$. One consensus solution would be a long-lived catalytic system for the splitting water to $\mathrm{H}_{2}$ and $\mathrm{O}_{2}$ by solar light with an energy efficiency of at least $10 \%$ [1]. To our knowledge, no truly homogeneous and efficient system for water splitting has been reported. The water oxidation half-reaction is particularly demanding requiring the transfer of four protons, four electrons and the formation of an oxygen-oxygen double bond. Despite this limitation several unique classes of WOCs have been reported. More than 30 years ago aqua or hydroxometal complexes of $\mathrm{Co}(\mathrm{II}), \mathrm{Ni}$ (II) and $\mathrm{Fe}(\mathrm{II})$ were found to be efficient water oxidation catalysts (WOCs) [2-7]. Recently WOCs based on tunable, carbon-free (thus non-oxidizable) early-transition-metal-oxygen anion clusters (polyoxometalates or "POMs") with Ru[8-10], $\operatorname{Ir}[11]$, and $\mathrm{Co}[12,13]$ active sites were reported. These include the Co-containing complex, $\left[\mathrm{Co}_{4}\left(\mathrm{H}_{2} \mathrm{O}\right)_{2}\left(\mathrm{PW}_{9} \mathrm{O}_{34}\right)_{2}\right]^{10-}(\mathbf{1})$. Additionally, Nocera et al [14-16] developed a series of water oxidation catalysts by electrodeposition of cobalt-oxide catalysts on anode surfaces from 
solutions of $\mathrm{Co}_{(\mathrm{aq})}{ }^{2+}$ in different buffers. Polyhydroxy Co complexes, Co-containing POMs, and electrodeposited cobalt-oxide have many structural, compositional and electronic features in common. The reaction mechanism of catalysis by polyhydroxy Co-complexes is not well established due to the complexity of these systems [2,5-7]. For example, experimental data collected in phosphate buffer [2,7] and the formation of minimally soluble Co-phosphate complexes were not taken into account in these previous studies. The initial Ru(bpy) ${ }_{3}{ }^{3+}$ concentration in one study [6] was significantly lower than in typical catalytic water oxidation processes using this terminal sacrificial electron acceptor. In addition, the fitting of the kinetics of catalytic reduction of $\left[\mathrm{Ru}(\mathrm{bpy})_{3}\right]^{3+}$ is now outdated. Here, we report a kinetic model of water oxidation catalyzed by aquacobalt(II) based on recent data collected with modern instrumental and computational capabilities.

\section{EXPERIMENTAL DETIALS}

\section{Materials}

$\mathrm{Na}_{10}\left[\mathrm{Co}_{4}\left(\mathrm{H}_{2} \mathrm{O}\right)_{2}\left(\mathrm{PW}_{9} \mathrm{O}_{34}\right)_{2}\right] \cdot 26 \mathrm{H}_{2} \mathrm{O}$ and tris(2,2'-bipyridyl)triperchlororuthenium(III), $\left(\left[\mathrm{Ru}(\mathrm{bpy})_{3}\right]\left(\mathrm{ClO}_{4}\right)_{3}\right)$, were prepared as described in the literature. Sodium persulfate, $\mathrm{Co}(\mathrm{NO})_{2} \cdot 6 \mathrm{H}_{2} \mathrm{O}$, and all other reagents were of the highest purity available from commercial sources. Tris(2,2'-bipyridyl)dichlororuthenium(II) hexahydrate ( $R u(\text { bipy })_{3}{ }^{2+}$ ), was purified before use by recrystallizing as described earlier [13]. Water for the preparation of solutions was obtained from a Barnstead Nanopure ${ }^{\circledast}$ water-purification system.

\section{$\underline{\text { UV-Vis measurements }}$}

UV-Vis spectra were acquired using Agilent 8453 spectrophotometer equipped with a diode-array detector and Agilent 89090A cell temperature controller unit. The solutions of 1 were dissolved in desired buffer solution in a quartz cuvette ( 1 or $10 \mathrm{~cm}$ path length), and absorbance at $579 \mathrm{~nm}$ was corrected by subtracting the absorbance at $800 \mathrm{~nm}$. The extinction coefficient at $580 \mathrm{~nm}$ determined to be $160 \mathrm{M}^{-1} \mathrm{~cm}^{-1}$.

\section{General procedure}

All stock solutions of 1 and $\mathrm{Co}\left(\mathrm{NO}_{3}\right)_{2}$ were prepared in water unless stated otherwise. The solutions of $\mathbf{1}$ were prepared immediately before use by dissolving solid $\mathbf{1}$.

\section{$\underline{\text { Light-driven catalytic experiments }}$}


The light-driven water oxidation was performed in a cylindrical cuvette (NSG, 32UV10) with a total volume of $\sim 2.5 \mathrm{ml}$. The cell was filled with $2.0 \mathrm{~mL}$ of reaction solution with $1.0 \mathrm{mM}$ $\mathrm{Ru}$ (bpy) ${ }_{3} \mathrm{Cl}_{2} \cdot 6 \mathrm{H}_{2} \mathrm{O}, 5.0 \mathrm{mM} \mathrm{Na} \mathrm{S}_{2} \mathrm{O}_{8}, 0.2-6.0 \mu \mathrm{M}$ catalyst (in $80 \mathrm{mM}$ sodium borate buffer (initial $\mathrm{pH}$ 9.0). The reaction cell was sealed with a rubber septum, carefully deairated and filled with Ar. All procedures were performed with a minimum exposure to ambient light. The reaction was initiated by turning on the LED-light source $(\lambda=455 \mathrm{~nm}$; light intensity $17 \mathrm{~mW}$, beam diameter $\sim 0.4 \mathrm{~cm}$ ). A magnetically-coupled stirring system (SYS 114, SPECTROCELL) was used to mix reaction solutions at $4 \times 10^{3} \mathrm{RPM}$. The $\mathrm{O}_{2}$ concentration in the headspace was quantified by GC. The solution $\mathrm{pH}$ was measured after the reaction.

Analysis of dioxygen in the reaction headspace was performed using a computer controlled Agilent 6850 model gas chromatograph equipped with a thermal conductivity detector and a HPMOLESIEVE capillary GC column $(30 \mathrm{~m}$ x $0.535 \mathrm{~mm}$ x $25.00 \mu \mathrm{m})$. Argon was used as a carrier gas. Typically, the $\mathrm{O}_{2}$ yield was quantified by withdrawing a gas sample from the headspace without stopping the reaction. Contamination of the head-space with air was corrected by quantification of $\mathrm{N}_{2}$ present in the head-space (from the $\mathrm{N}_{2}$ peak in the GC traces).

\section{$\left.\underline{\text { Kinetics of catalytic }[\mathrm{Ru}(\mathrm{bpy})} \mathrm{B}_{3}\right]^{3+}$ reduction}

The reactions were studied using a Hi-Tech Stopped Flow SF-61SX2 instrument equipped with a diode array detector operating in wavelength range 400-700 $\mathrm{nm}$. One of the feeding syringes was filled with $\left[\mathrm{Ru}(\mathrm{bpy})_{3}\right]^{3+}$ solution and the other with a freshly prepared solution of the catalyst. The stock solution of 1 was in water. Each data set included 200 spectra collected with different timescales: from 0-0.4 s up to 0-400 s. Typically, the consumption of $\left[\mathrm{Ru}(\mathrm{bpy})_{3}\right]^{3+}$ was followed by a decrease in absorbance at $670 \mathrm{~nm}\left(\varepsilon_{670}=4.2 \times 10^{2} \mathrm{M}^{-1} \mathrm{~cm}^{-1}\right)$ with optical path length $l=10 \mathrm{~mm}$. The data were acquired and treated using KinetAsyst ${ }^{\mathrm{TM}} 3.0$ software. Detailed analysis of kinetic data was performed using Gepasi v 3.30 software [17].

\section{DISCUSSION}

We evaluated the catalytic behavior of Co-containing WOCs in borate buffer to avoid the formation of cobalt phosphate complexes. The activity of $\mathrm{Co}\left(\mathrm{NO}_{3}\right)_{2}(\mathrm{Co}(\mathrm{II})$ source) as a WOC using $\mathrm{Ru}(\mathrm{bpy})_{3}{ }^{3+}$ as a sacrificial oxidant was studied following the kinetics of $\mathrm{Ru}(\mathrm{bpy})_{3}{ }^{3+}$ reduction by UV-Vis as performed previously $[12,13]$. The kinetic profile of reactions catalyzed by $\mathrm{Co}$ (II) can be best understood by analysis of the rate equations in eqs 1-9. The initial slow portion of the curve corresponds to an induction period as the active catalyst is formed as described in eqs 1 and 2. Once the active catalyst is formed the water oxidation steps proceed (eqs 2-7). The second segment of the curve does not fit typical exponential decay as it includes self-inhibition (eq 9) and competing precipitation (eq 8). The kinetic profile of water oxidation catalyzed by 1 does not exhibit an induction period. This strongly suggests that there is no 
conversion of 1 to another species on the kinetic timescale as has been recently suggested [18]. The shape of the curve, however, also does not fit exponential decay which is consistent with self-inhibition and competing reactions.

$$
\begin{aligned}
& \mathrm{Co}\left(\text { II) } \stackrel{\mathrm{k}_{1}}{\longrightarrow} \mathrm{Co}(\text { III })\right. \\
& \mathrm{Co}\left(\text { III) } \stackrel{\mathrm{k}_{2}}{\longrightarrow} \mathrm{Cat}(0)\right. \\
& \mathrm{Ru}^{3+}+\mathrm{Cat}(0) \stackrel{\mathrm{k}_{3}}{\longrightarrow} \mathrm{Ru}^{2+}+\mathrm{Cat}(1) \\
& \mathrm{Ru}^{3+}+\mathrm{Cat}(1) \stackrel{\mathrm{k}_{4}}{\longrightarrow} \mathrm{Ru}^{2+}+\mathrm{Cat}(2) \\
& \mathrm{Ru}^{3+}+\mathrm{Cat}(2) \stackrel{\mathrm{k}_{5}}{\longrightarrow} \mathrm{Ru}^{2+}+\mathrm{Cat}(3) \\
& \mathrm{Ru}^{3+}+\mathrm{Cat}(3) \stackrel{\mathrm{k}_{6}}{\rightleftharpoons} \mathrm{Ru}^{2+}+\mathrm{Cat}(4) \\
& \mathrm{Cat}(4) \stackrel{\mathrm{k}_{6}}{\longrightarrow} \text { Cat }(0)+\mathrm{O}_{2} \\
& \mathrm{Cat}(3) \stackrel{\mathrm{k}_{8}}{\longrightarrow} \text { Precipitation } \\
& \mathrm{Ru}^{3+}+\mathrm{Cat}(4) \stackrel{\mathrm{k}_{9}}{\longrightarrow} \mathrm{Ru}^{2+}+\mathrm{Cat}(2)
\end{aligned}
$$

where Cat(n) is a polynuclear complex and " $n$ " is the number of electrons withdrawn from $\operatorname{Cat}(0), \mathrm{Ru}^{\mathrm{n}+}$ is $\mathrm{Ru}(\mathrm{bpy})_{3}{ }^{\mathrm{n}+}$, and $\mathrm{Ru}(\mathrm{bpy})_{3}{ }^{2+{ }^{+}}$is $\mathrm{Ru}(\mathrm{bpy})_{3}{ }^{2+}$ with some oxidized bpy ligand. Eq 8 is an irreversible deactivation of Co complex. Eq 9 is a simple representation for catalytic oxidation of the photosensitizer ligand.

The eq 6 is the removal of the fourth electron from the catalyst and is considered a reversible reaction. Cat(4) (analogous to $2 \mathrm{CoO}_{2}$ in the Stahl, Casey et al. study [19]) is a strong oxidant thermodynamically able to oxidize water via 4-e pathway in eq 10 (written in eq 7 as an unimolecular process).

$$
2 \mathrm{CoO}_{2}+2 \mathrm{H}_{2} \mathrm{O} \stackrel{\mathrm{k}_{10}}{\longrightarrow} 2 \mathrm{HCoO}_{2}^{-}+2 \mathrm{H}^{+}+\mathrm{O}_{2}
$$

The kinetic model was based, in part, on the most recent Pourbaix diagram for Co(II) [19] but operates with several limitations. The diagram was based on a cobalt concentration of $[\mathrm{Co}(\mathrm{II})]=10^{-7} \mathrm{M}$, which is about one order of magnitude lower than the catalytic conditions used here. At higher $[\mathrm{Co}(\mathrm{II})]$ concentrations the formation of polynuclear complexes are more favorable. Ion paring with sodium cation (from the buffer) was not taken into account for simplicity despite its involvement in several aqueous cobalt redox equlibria [19]. In addition, the reaction of $\left[\mathrm{Ru}(\mathrm{bpy})_{3}\right]^{3+}$ self-decomposition (in the absence of a catalyst) is slow (Figure 1) [7] and was not considered for simplicity. Under similar experimental conditions, the intermediate 
formation of discrete $\mathrm{H}_{2} \mathrm{O}_{2}$ was ruled out [6]. However, if this process was included in the kinetic model, it would be kinetically indistinguishable from the model.
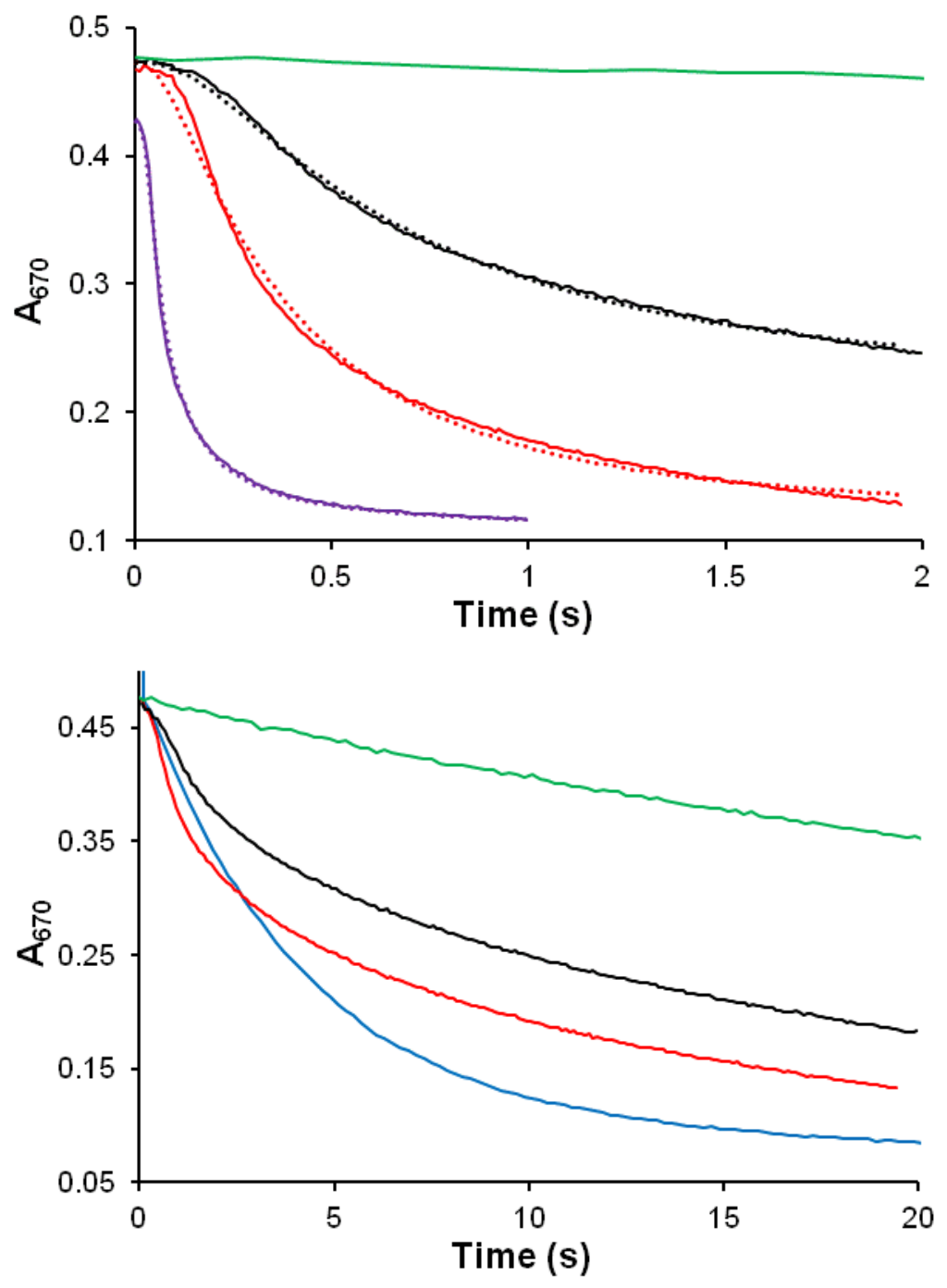

Figure 1. The decay of $\left[\mathrm{Ru}(\mathrm{bpy})_{3}\right]^{3+}$ (absorbance at $670 \mathrm{~nm}$ ) via water oxidation catalyzed by $\mathrm{Co}\left(\mathrm{NO}_{3}\right)_{2}$ and 1 in $80 \mathrm{mM}$ sodium borate buffer at $20{ }^{\circ} \mathrm{C}$ Top: $\mathrm{pH} 8.0 ; 1.15 \mathrm{mM}\left[\mathrm{Ru}(\mathrm{bpy})_{3}\right]^{3+}$ (initial); 0, 2.0, and 5.0 $\mu \mathrm{M} \mathrm{Co}\left(\mathrm{NO}_{3}\right)_{2}$ (green, black and red, respectively). $\mathrm{pH} 9.0 ; 1.0 \mathrm{mM}$ $\left[\mathrm{Ru}(\mathrm{bpy})_{3}\right]^{3+}$ (initial), $5.0 \mu \mathrm{M} \mathrm{Co}\left(\mathrm{NO}_{3}\right)_{2}$ (purple). Dotted lines are fits to eqs 1-9. Bottom: $\mathrm{pH} 8.0$; $1.15 \mathrm{mM}\left[\mathrm{Ru}(\mathrm{bpy})_{3}\right]^{3+}$ (initial); 0, 0.5, and $1.0 \mu \mathrm{M} \mathrm{Co}\left(\mathrm{NO}_{3}\right)_{2}$ (green, black and red, respectively) or $3 \mu \mathrm{M} 1$ (blue).

Very good fits of the experimental data to eqs $1-9$ (Figure 1 ) affords $\mathrm{K}_{6} \approx 0.04, \mathrm{k}_{7} \approx 10^{6} \mathrm{~s}^{-1}$ and $\mathrm{K}_{6} \approx 1, \mathrm{k}_{7} \approx 10^{4} \mathrm{~s}^{-1}$ at $\mathrm{pH} 8.0$ and 9.0, respectively. This is consistent with more favorable reaction thermodynamics in eqs 6-7. At the same time, the apparent rate constant for the precipitation in eq 9 increases from $\approx 1 \times 10^{1}$ to $\approx 2 \times 10^{2} \mathrm{~s}^{-1}$, which is again consistent with lower solubility of Co-polyhydroxo species at higher $\mathrm{pH}$. The rate constants obtained from fitting to 
eqs 2-9, are not completely confirmed as the fitting is based on a limited number of experimental data. In addition, the $\mathrm{O}_{2}$ yield in the end of reactions shown in Figure 2 was not measured.

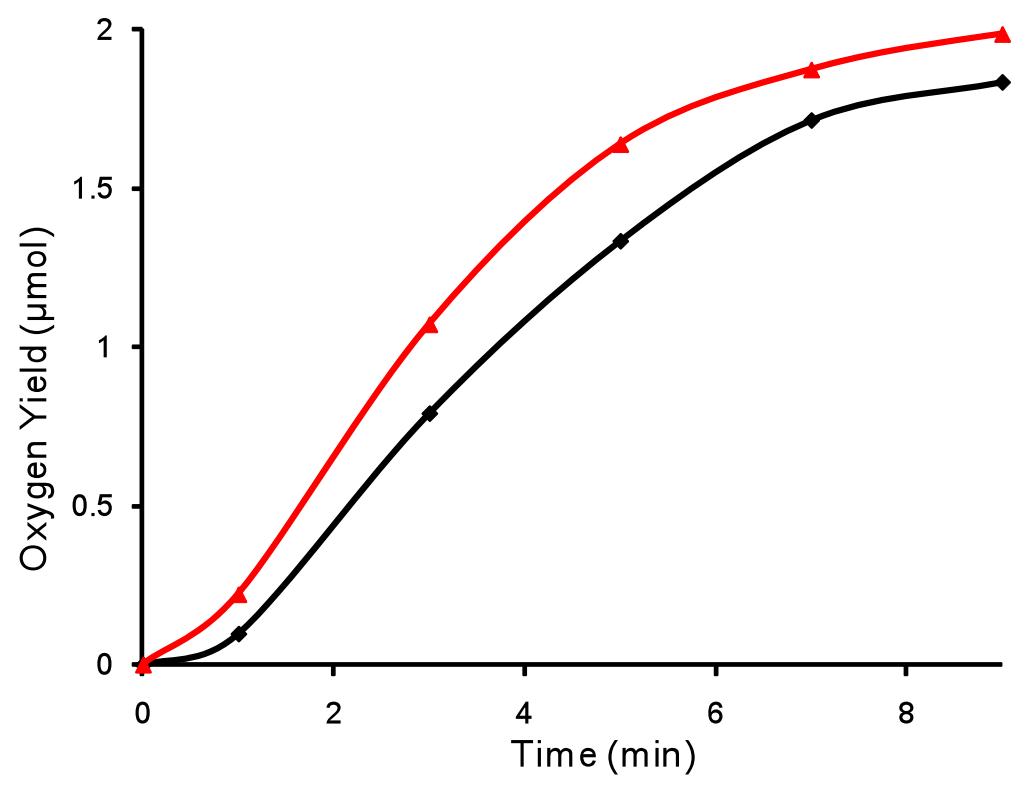

Figure 2. The $\mathrm{O}_{2}$-formation catalyzed by $2 \mu \mathrm{M} \mathrm{Co}\left(\mathrm{NO}_{3}\right)_{2}$ in $80 \mathrm{mM}$ borate buffers at $\mathrm{pH} 8$ and 9 (black and red curves, respectively). Conditions: $455 \mathrm{~nm}$ LED-light beam with optical diameter $\approx 0.4 \mathrm{~cm}$ and $17 \mathrm{~mW}$ was focused on the flat front wall of the reaction vessel; $1.0 \mathrm{mM}$ $\left[\mathrm{Ru}(\mathrm{bpy})_{3}\right]^{2+}, 5.0 \mathrm{mM} \mathrm{Na} \mathrm{S}_{2} \mathrm{O}_{8}$, vigorous agitation by the magnetic stirring bar at $4 \times 10^{3} \mathrm{RPM}$.

We also measured the $\mathrm{O}_{2}$ formation versus time in a light driven system as in our previous study (Figure 2) [13]. In the absence of catalyst a small amount of dioxygen was formed: $<10 \%$ compared with those that in catalytic runs and this amount was subtracted from the $\mathrm{O}_{2}$ yields.

The curves in Figure 2 display a similar induction period to the water oxidation system using $\left[\mathrm{Ru}(\mathrm{bpy})_{3}\right]^{3+}$ as a stoichiometric oxidant. Again, this indicates that the initial Co(II) is a precursor of the catalytically active species as seen experimentally in both catalytic systems and fitting from the kinetic model in eqs 1-9. Importantly, despite a significant difference in the rates of observed $\mathrm{Ru}(\mathrm{bpy}) 3_{3}{ }^{3+}$ reduction when the $\mathrm{pH}$ changes from 8 to 9 , there is almost no difference in $\mathrm{O}_{2}$ formation rates in the light driven process with this same change in $\mathrm{pH}$. This indicates that the rates in Figure 2 are largely governed by the light intensity, which affects the rate of $\mathrm{Ru}(\mathrm{bpy}) 3^{3+}$ generation. As a result, the turnover frequency of a catalyst cannot be determined from the slopes in Figure 2.

The $\mathrm{O}_{2}$ yield in light driven reactions quickly increases with catalyst concentration and then slowly reaches a plateau show in Figure 3. As a result the turnover number $\left(\mathrm{TON}=\left(\mathrm{O}_{2}\right) /(\mathrm{cat})\right)$ quickly decreases with catalyst concentration. The maximum yield $\left(\mathrm{O}_{2}\right) /(2$ persulfate $)$ under conditions in Figure 3 at pH 9 approaches c.a. 50\% based on eq 11. The kinetic model in eqs 1-9 is not applicable for the light driven process because a photon flux is unevenly distributed in 
$2 \mathrm{~S}_{2} \mathrm{O}_{8}^{2-}+2 \mathrm{H}_{2} \mathrm{O} \stackrel{\mathrm{k}_{11}}{\longrightarrow} 4 \mathrm{SO}_{4}^{2-}+4 \mathrm{H}^{+}+\mathrm{O}_{2}$

solution. Yields lower than $100 \%$ indicate a significant contribution of side reactions catalyzed by $\mathrm{Co}(\mathrm{II})$ such as in eq 9 . The oxidation of bpy-ligand produces numerous products up to $\mathrm{CO}_{2}$ $[4,5,7]$.

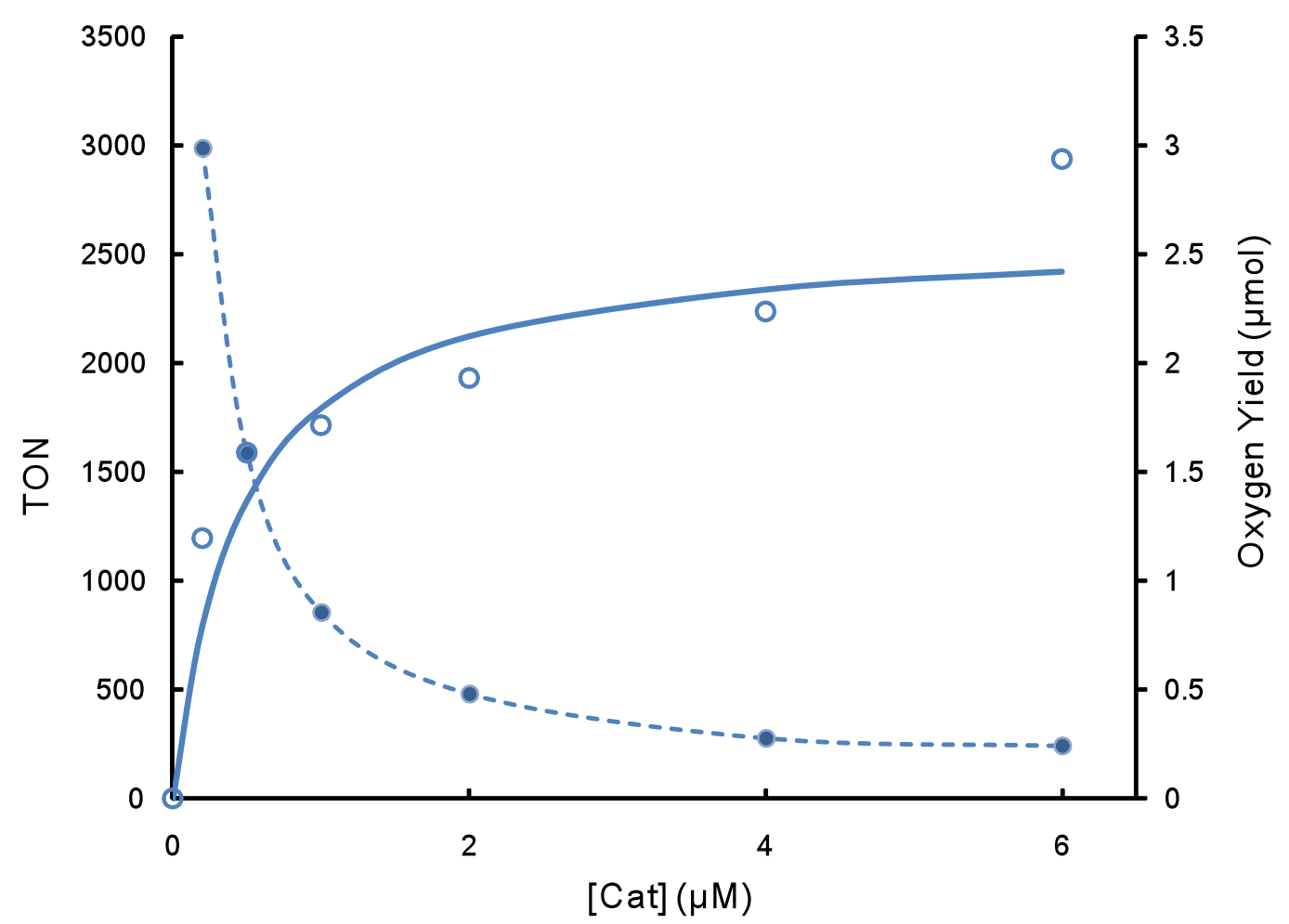

Figure 3. The $\mathrm{O}_{2}$ yield in the light driven reaction catalyzed by $\mathrm{Co}\left(\mathrm{NO}_{3}\right)_{2}$ in $80 \mathrm{mM}$ borate buffer at $\mathrm{pH} 9$. Conditions: $455 \mathrm{~nm}$ LED-light beam with $\mathrm{OD} \approx 0.4 \mathrm{~cm}$ and $17 \mathrm{~mW}$ focused on the flat front wall of the reaction vessel; $1.0 \mathrm{mM}\left[\mathrm{Ru}(\text { bpy })_{3}\right]^{2+}, 5.0 \mathrm{mM} \mathrm{Na} \mathrm{S}_{2} \mathrm{O}_{8}$, vigorous agitation by the magnetic stirring bar at $4 \times 10^{3}$ RPM.

\section{CONCLUSIONS}

$\mathrm{Co}(\mathrm{II})$ is an efficient water oxidation catalyst but with a fundamentally different kinetic profile than other molecular WOCs. A simplified kinetic model was constructed and supported by fitting to the experimental curves. Work regarding quantification of relative rates of water oxidation versus competing decomposition reactions is in progress for similar catalytic systems.

\section{ACKNOWLEDGMENTS}

CLH wishes to thank the U.S. Department of Energy, Office of Basic Energy Sciences, 
Catalysis and Chemical Transformations program, grant number DE-FG02-03ER15461 for support 


\section{REFERENCES}

[1] A.J. Bard and M.A. Fox, Acc. Chem. Res. 28 (3), 141-145 (1995).

[2] B.S. Brunschwig, M.H. Chou, C. Creutz, P. Ghosh and N. Sutin, J. Am. Chem. Soc. 105 4832-4833 (1983).

[3] A. Harriman, G. Porter and P. Walters, J. Chem. Soc. Faraday Trans. 277 2373-2383 (1981).

[4] N.K. Khannanov and V.Y. Shafirovich, Doklady Akademii Nauk SSSR 260 (6), 14181421 (1981).

[5] N.K. Khannanov, A.V. Khramov, A.P. Moravskii and V.Y. Shafirovich, Kinetika i Kataliz 24 (4), 858-864 (1983).

[6] A.P. Moravskii, A.P. Khannanov and A.V. Khramov, Khimicheskaya Fizika 3 (11), 1584-1590 (1984).

[7] P.K. Ghosh, B.S. Brunschwig, M. Chou, C. Creutz and N. Sutin, J. Am. Chem. Soc. 106 4772-4783 (1984).

[8] Y.V. Geletii, B. Botar, P. Kögerler, D.A. Hillesheim, D.G. Musaev and C.L. Hill, Angew. Chem. Int. Ed. 47 3896-3899 (2008).

[9] A. Sartorel, M. Carraro, G. Scorrano, R.D. Zorzi, S. Geremia, N.D. Mcdaniel, S. Bernhard and M. Bonchio, J. Am. Chem. Soc 130 (15), 5006-5007 (2008).

[10] Y.V. Geletii, Z. Huang, Y. Hou, D.G. Musaev, T. Lian and C.L. Hill, J. Am. Chem. Soc. $1317522-7523$ (2009).

[11] R. Cao, H. Ma, Y.V. Geletii, K.I. Hardcastle and C.L. Hill, Inorg. Chem. 48 5596-5598 (2009).

[12] Q. Yin, J.M. Tan, C. Besson, Y.V. Geletii, D.G. Musaev, A.E. Kuznetsov, Z. Luo, K.I. Hardcastle and C.L. Hill, Science 328 342-345 (2010).

[13] Z. Huang, Z. Luo, Y.V. Geletii, J. Vickers, Q. Yin, D. Wu, Y. Hou, Y. Ding, J. Song, D.G. Musaev, C.L. Hill and T. Lian, J. Am. Chem. Soc. 133 2068-2071 (2011).

[14] M.W. Kanan and D.G. Nocera, Science 321 1072-1075 (2008).

[15] M.W. Kanan, Y. Surendranath and D.G. Nocera, Chem. Soc. Rev. 38 109-114 (2009).

[16] D.A. Lutterman, Y. Surendranath and D.G. Nocera, J. Am. Chem. Soc. 131 3838-3839 (2009).

[17] P. Mendes, Vol. 9, Comput. Applic. Biosci., 1997, pp. 563-571. 
[18] J.J. Stracke and R.G. Finke, J. Am. Chem. Soc. 133 14872-14875 (2011).

[19] J.B. Gerken, J.G. Mcalpin, J.Y.C. Chen, M.L. Rigsby, W.H. Casey, R.D. Britt and S.S. Stahl, J. Am. Chem. Soc. 133 14431-14442 (2011). 